Прокопенко О. С. (ORCID 0000-0002-5482-0317);

Рибидайло А. А., к.т.н., с.н.c. (ORCID 0000-0002-6156-469X);

Турейчук А. М., к.т.н. (ORCID 0000-0002-4837-500X);

Руденська Г. В. (ORCID 0000-0002-4719-3765)

Центр воєнно-стратегічних досліджень Національного університету оборони України імені Івана Черняховського, Київ

\title{
Ключові показники ефективності управління організаційною структурою збройних сил
}

Резюме. Розглянуті питання обгрунтування, розроблення та впровадження ключових показників ефективності управління організаційною структурою Збройних Сил України.

Ключові слова: КРІ; ключовий показник ефективності; організаційна структура; планування організаційної структури на основі спроможностей; доктрина DOTMLPF; DRMIS.

Постановка проблеми. Організаційний менеджмент $є$ одним 3 ключових напрямів діяльності організації, планування, гнучке використання якого дає змогу ефективно використовувати підрозділи та організаційні структури для вирішення усього спектру завдань організації. Для управління організаційною структурою $3 \mathrm{C}$ України доцільно використовувати засоби бізнесаналітики. За такої умови формуються ключові показники ефективності (Кеу Performance Indicators, KPI), використання яких надає можливість керівництву коригувати план реалізації стратегії, тобто порядок досягнення визначених стратегічних, операційних і тактичних цілей [1].

Аналіз останніх досліджень i публікацій. KPI - інструмент вимірювання визначених цілей. Якщо показник не пов'язаний $з$ метою, тобто не утворюється виходячи 3 іiі змісту, тоді неможна використовувати цей показник як KPI. Технології постановки, перегляду і контролю цілей і завдань лягли в основу концепції, яка стала основою сучасного управління i називається "Управління по цілям".

Головним поточним завданням ефективного реагування загрозам національній безпеці у воєнній сфері, оборони України, захисту іiі суверенітету, територіальної цілісності та недоторканості $є$ реалізація Державної Програми розвитку Збройних Сил України на період до 2020 року [2] (далі - Державна Програма). Одними 3 основних шляхів досягнення мети Державної Програми є: автоматизація процесів управління та обліку; професіоналізація особового складу; підготовка та оцінювання готовності відповідно до стандартів НАТО; перехід до системи оборонного планування, основаної на спроможностях. Цей нормативноправовий акт $\epsilon$ узагальнюючим документом щодо реалізації Стратегічного оборонного бюлетеню України [3], виробленого на основі правових актів [3-7].

Автоматизація процесу аналізу поточного стану та оцінювання реалізації виконаних завдань Державної Програми у проекції організаційного менеджменту, як основи планування та ефективного застосування оборонних ресурсів, потребує ретельного опрацювання ключових показників ефективності.

Одним 3 основоположників системи оцінювання досягнення результатів - цілей через ключові показники ефективності є Пітер Друкер [8]. На його думку "Управління по цілям" дає змогу компанії досягти успіху, не піддавшись так званим “пасткам часу”, коли керівники підрозділів компанії приділяють достатньо уваги буденним, рутинним завданням, та відхиляються від виконання основних стратегічних завдань для досягнення намічених результатів. Іншими теоретиками принципів і правил впровадження КРI були вчені Гарвардської школи бізнесу Роберт Каплан та Девід Нортон, які розробили модель збалансованої системи показників, що $\epsilon$ способом прив'язки поточних дій компанії до довгострокових цілей [9].

$$
\text { У міжнародній практиці }
$$
використання KPI набуло широке розповсюдження в економіці, сучасному бізнесі, управлінні людськими ресурсами та багатьох інших інноваційних підприємствах, основною метою яких $\epsilon$ отримання максимального прибутку - досягнення ключових факторів успіху. Проте у доступних 
публікаціях недостатньо уваги було приділено формуванню KРI для воєнного відомства.

Мета статті. Обгрунтування пропозицій щодо розроблення ключових показників ефективності управління організаційною структурою Збройних Сил України, використання яких в інформаційноаналітичній системі (IAC), як складової єдиної інформаційної системи управління оборонними ресурсами (DRMIS), підвищить ефективність планування, прийняття управлінських рішень керівництвом Збройних Сил та моніторингу поточного стану по визначених цілях.

\section{Виклад основного матеріалу.} Організаційна структура Збройних Сил України це складна система, яка $є$ сукупністю ієрархічно взаємозв'язаних організаційних елементів, що здійснюють свою діяльність на підставі виконання певних функцій і завдань. Організаційна структура є основою структури управління, організаційно закріплює управлінські функції за підрозділами та слугує мережею каналів якими рухаються потоки інформації.

Існує дві групи факторів управління структурою - зовнішні та внутрішні [11].

До зовнішніх факторів належать:

стан i тенденції розвитку воєннополітичної обстановки, прогнозовані види та рівні воєнних загроз;

характер майбутньої збройної боротьби, форми і способи застосування в них військ (сил);

стан, основні параметри i напрями розвитку збройних сил, озброєння і військової техніки суміжних та інших країн.

Внутрішніми факторами є:

стан Збройних Сил України, ступінь їх відповідності спроможностям для гарантованої відсічі збройній агресії, оборони держави та участі у підтриманні миру i міжнародної безпеки;

прогнозовані можливості держави щодо забезпечення оборонних потреб необхідними ресурсами (людськими, фінансовими, матеріальними);

$$
\text { стан i можливості оборонно- }
$$

промислового комплексу;

національне законодавство у сфері оборони, у тому числі можливість використання в інтересах оборони поряд зі Збройними Силами інших військових формувань та правоохоронних органів.

Основні нормативно-правові документи, якими регламентуються процеси управління організаційною структурою $3 \mathrm{C}$ України наведені у табл. 1.

Таблиця 1

\begin{tabular}{|c|c|c|c|}
\hline $\begin{array}{l}\text { № } \\
\text { 3/II }\end{array}$ & Категорія акта & Дата підписання & Назва \\
\hline 1 & $\begin{array}{l}\text { Закон України } \\
\text { № 1934-XII } \\
\end{array}$ & 06.12 .1991 & Про Збройні Сили України \\
\hline 2 & Закон України & $\begin{array}{l}21.06 .2018 \\
\text { № } 2469 \text {-VIII }\end{array}$ & Про національну безпеку України \\
\hline 3 & Закон України & $\begin{array}{l}\text { Відомості Верховної Ради } \\
\text { України (ВВР), 2010, } \\
\text { № 40, ст. } 527\end{array}$ & Про засади внутрішньої і зовнішньої політики (із змінами) \\
\hline 4 & Закон України & $\begin{array}{l}\text { Відомості Верховної Ради } \\
\text { України (ВВР), 1992, № 9, } \\
\text { ст. } 106\end{array}$ & Про оборону України \\
\hline 5 & Закон України & 21.10 .1993 & Про мобілізаційну підготовку та мобілізацію (із змінами) \\
\hline 6 & $\begin{array}{l}\text { Указ Президента } \\
\text { України }\end{array}$ & 26.05.2015 & $\begin{array}{l}\text { Про рішення Ради національної безпеки і оборони } \\
\text { України від 06.05.2015 “Про Стратегію національної } \\
\text { безпеки України” }\end{array}$ \\
\hline 7 & $\begin{array}{lr}\text { Указ } & \text { Президента } \\
\text { України № 73/2017 }\end{array}$ & 22.03.2017 & $\begin{array}{l}\text { Про рішення Ради національної безпеки і оборони } \\
\text { України від 29.12.2016 “Про Державну програму розвитку } \\
\text { Збройних Сил України на період до } 2020 \text { року” }\end{array}$ \\
\hline 8 & $\begin{array}{lr}\text { Указ Президента } \\
\text { України № 92/2016 }\end{array}$ & 14.03.2016 & $\begin{array}{l}\text { Про рішення Ради національної безпеки і оборони } \\
\text { України від 04.04.2016 року “Про Концепцію розвитку } \\
\text { сектору безпеки і оборони України” }\end{array}$ \\
\hline 9 & $\begin{array}{l}\text { Додаток до Указу } \\
\text { Президента } \\
\text { України № 92/2016 }\end{array}$ & 14.03.2016 & $\begin{array}{l}\text { Розподіл відповідальності складових сектору безпеки і } \\
\text { оборони України за організацію планування, реагування } \\
\text { на загрози та під час виконання завдань за призначенням }\end{array}$ \\
\hline 10 & $\begin{array}{l}\text { Указ Президента } \\
\text { України } \\
\text { № 240/2016 }\end{array}$ & 06.06 .2016 & $\begin{array}{l}\text { Про рішення Ради національної безпеки і оборони } \\
\text { України від 20.05.2016 "Про Стратегічний оборонний } \\
\text { бюлетень України" }\end{array}$ \\
\hline 11 & $\begin{array}{l}\text { Указ Президента } \\
\text { України } \\
\text { № 555/2015 } \\
\end{array}$ & 24.09.2015 & $\begin{array}{l}\text { Про рішення Ради національної безпеки і оборони } \\
\text { України від 02.09.2015 “Про нову редакцію Воєнної } \\
\text { доктрини України” }\end{array}$ \\
\hline 12 & $\begin{array}{l}\text { Розпорядження } \\
\text { Кабінету Міністрів } \\
\text { України № 139- p }\end{array}$ & 25.02.2015 & $\begin{array}{l}\text { Про затвердження } \text { плану } \\
\text { комплексного оглодів } 3 \text { проведенення сектору безпеки і оборони України } \\
\text { та методичних рекомендацій щодо його проведення }\end{array}$ \\
\hline
\end{tabular}




\begin{tabular}{|c|l|l|l|}
\hline $\begin{array}{c}\text { № } \\
\text { 3/п }\end{array}$ & Категорія акта & \multicolumn{1}{|c|}{ Дата підписання } & \multicolumn{1}{|c|}{ Назва } \\
\hline 13 & $\begin{array}{l}\text { Наказ МО України } \\
\text { № } 303\end{array}$ & 13.05 .2013 & $\begin{array}{l}\text { Рекомендації 3 організації та проведення оборонного } \\
\text { огляду }\end{array}$ \\
\hline 14 & $\begin{array}{l}\text { Наказ МО України } \\
\text { № } 670\end{array}$ & $\begin{array}{l}\text { Про організацію оборонного планування в Міністерстві } \\
\text { оборони України і Збройних Силах України у 2018 році } \\
\text { на 2019-2021 роки }\end{array}$ \\
\hline 15 & $\begin{array}{l}\text { Затверджено } \\
\text { Міністром } \\
\text { Оборони України }\end{array}$ & $\begin{array}{l}\text { План дій щодо впровадження оборонної реформи у } \\
2016-2020 \text { роках (дорожня карта оборонної реформи) }\end{array}$ \\
\hline
\end{tabular}

Аналіз

нормативно-правових

документів (табл. 1) дає змогу сформулювати перелік необхідних вихідних даних для здійснення організаційного менеджменту у збройних силах:

оцінювання

воєнно-політичної

обстановки та визначення основних загроз національній безпеці і національним інтересам України у різних сферах (табл. 1, п. 2, 6, 8), від яких залежать функції і завдання, чисельний склад Збройних Сил України та дислокація частин і підрозділів (табл. 1, п. 2, 4, 8, 11), враховуючи сутність i характер сучасних воєнних конфліктів, принципи i шляхи запобігання їх виникненню (табл. 1, п 8, 11);

аудит економічних спроможностей держави щодо потреб Збройних Сил України у ресурсному забезпеченні, виконання завдань оборонно-промислового комплексу у розробленні новітніх зразків озброєння i військової техніки, їх серійного виробництва, а також створенні мобілізаційних ресурсів (табл. 1, п. 2, 6, 7);

аналіз набутого досвіду ведення локальних війн та збройних конфліктів у світі та під час ведення бойових дій на Сході України (табл. 1, п. 2, 6, 10, 11), його врахування при проведенні навчань та тренувань частин i підрозділів, для повноцінного використання їх бойового потенціалу під час виконання поставлених завдань 3 оборони територіальної цілісності та недоторканості України.

Відповідно до положень (табл. 1, п. 8) на підставі аналізу актуальних загроз національній безпеці України прораховуються імовірні кризові ситуації, на вирішення яких формуються варіанти сценаріїв для їх вирішення. При цьому для врегулювання ситуацій можуть залучатися 3С України, в тому числі і в якості відповідальної складової сектору безпеки і оборони України.

Оскільки сценаріїв вирішення кризової ситуації теоретично може бути декілька, організаційна структура має відповідати спроможностям щодо їх вирішення.

Спроможність - це здатність структурної одиниці (елементу) Збройних Сил України (сил оборони) або сукупності сил $\mathrm{i}$ засобів виконувати певні завдання (забезпечувати реалізацію визначених військових цілей) за певних умов обстановки (табл. 1, п. 7, 12, 14).

Оборонне планування на основі спроможностей дає змогу спрямувати зусилля на розвиток спроможностей сил оборони для ефективної протидії загрозам та ризикам, як військового, так і невійськового характеру 3 урахуванням імовірних сценаріїв розвитку кризових ситуацій. Процеси планування на основі спроможностей покладені в доктрину DOTMLPF [12], яка використовується в оборонному плануванні збройних сил державчленів НАТО.

DOTMLPF окремо взятої спроможності базується на таких критеріях:

$\boldsymbol{D}$ (Doctrine, доктрина) - опис вимог до спроможності, вимоги до виконання поставлених завдань;

$\boldsymbol{O}$ (Organization, $\quad$ організаційна структура) - організаційна структура, на яку покладається забезпечення виконання поставлених завдань;

$\boldsymbol{T}$ (Training, підготовленість) - навчання особового складу, його підготовка до вимог, яка забезпечує виконанню поставленого завдання;

M (Materiel, ресурси) - забезпеченість озброєнням, технікою, матеріальними, спеціальними та іншими засобами;

$\boldsymbol{L}$ (Leadership, керівництво) - ієрархічна (функціональна) підпорядкованість, структура управління;

$\boldsymbol{P}$ (Personnel, особовий склад) - наявний особовий склад, його знання, вміння та навички;

$\boldsymbol{F}$ (Facilities, об' єкти, споруди) - споруди, об'єкти місцевості, райони розташування на місцевості, інженерне обладнання.

Цей принцип нещодавно почав впроваджуватися i у процесах оборонного планування Збройних Сил України [13]. На етапі оцінювання відповідності вимогам спроможності для вирішення кризової ситуації за обраним сценарієм, до набутої спроможності організаційно-штатної структури (ії елементів), за критеріями оцінювання (DOTMLPF) пропонується ввести ключові показники 
ефективності (КРI). Для цього необхідно системі управління оборонними ресурсами розробити i впровадити бізнес-аналітичне (DRMIS). Джерелом для аналізу має бути рішення, яке буде функціонувати в Єдиній актуальна база даних системи.

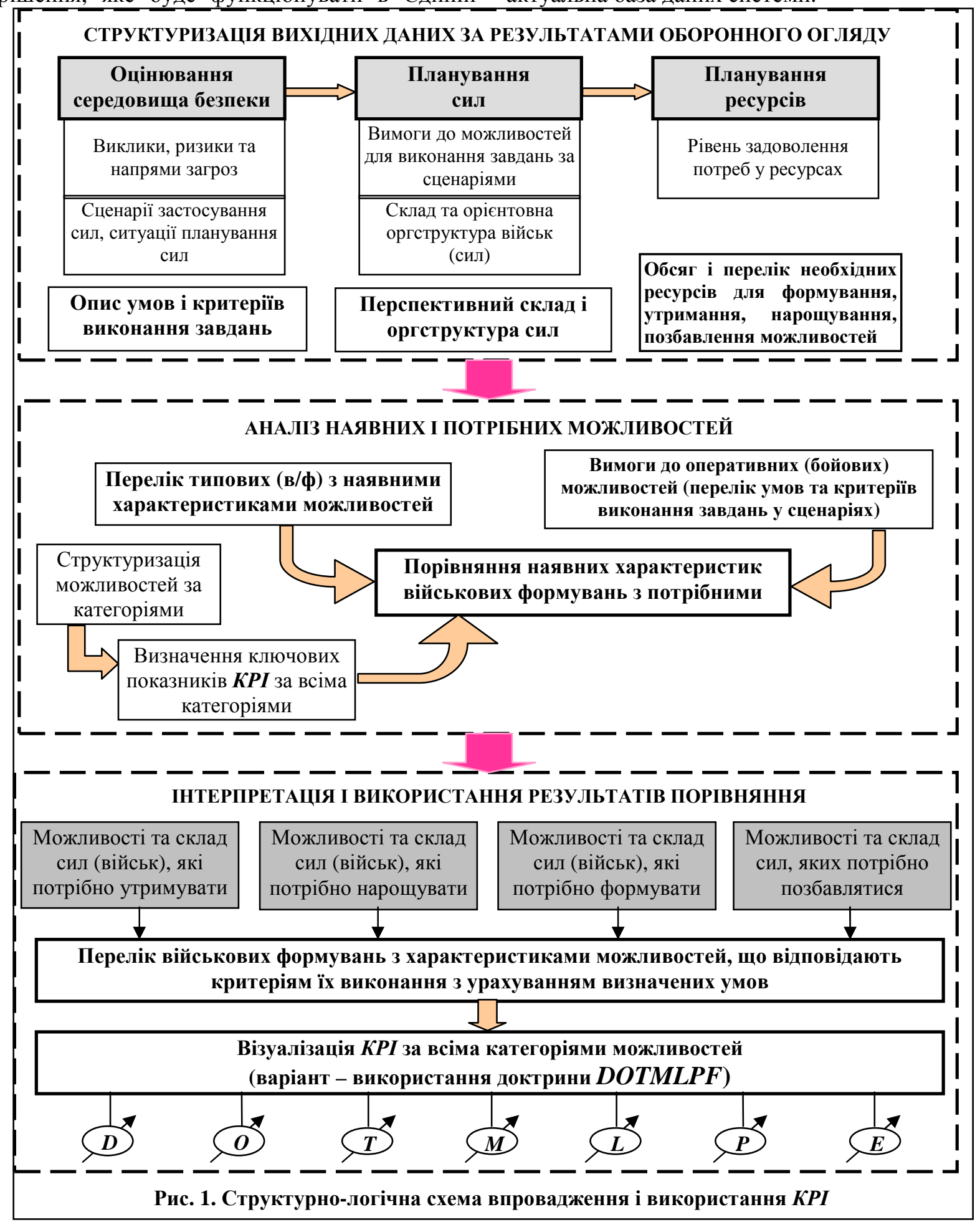

На рис. 1 показана узагальнена структурно-логічна схема впровадження i використання $\boldsymbol{K P I}$, яка містить три блоки:

структуризація вихідних даних за результатами оборонного огляду;

аналіз наявних i потрібних можливостей;

інтерпретація і використання результатів порівняння.
Під час оборонного

огляду здійснюється: оцінювання воєнно-політичної обстановки, викликів і загроз воєнній безпеці, тенденцій їх розвитку;

розроблення та оцінювання сценаріїв застосування, ситуацій планування сил для виконання визначених завдань; 
аналіз, оцінка та уточнення необхідних

можливостей (спроможностей) उС за визначеними сценаріями та ситуаціями; необхідні оперативні (бойові) можливості військ (сил); моніторинг стану ЗС (системи управління; кадрова політика; робота з особовим складом; військова освіта); оснащення Збройних Сил України озброєнням і військовою технікою; підготовка військ; матеріально-технічне забезпечення військ (сил); медичне забезпечення; військова інфраструктура; економічна і господарська діяльність МО;

формується перспективна модель ЗС України (система управління, підготовка військ (сил), оснащення сучасними системами (зразками) озброєння, спеціальною і військовою технікою, забезпечення ресурсами тощо) та стратегія іiї досягнення;

У другому блочі за визначеними ключовими показниками $\boldsymbol{K P I}$ здійснюється порівняння наявних характеристик військових формувань 3 потрібними

Результатом впровадження може бути робочий стіл керівника органу управління 3 індикацією показників автоматизованої оцінки сукупності критеріїв, де у відсотковому відношенні демонструється актуальний стан досягнутих спроможностей. Візуалізація аналітично обробленої інформації у зручній, сприятливій формі (третій блок) пришвидшить усвідомлення посадовою особою органу управління про динаміку змін того чи іншого показника за звітний період [14]. При наявності системи підтримки прийняття управлінських рішень (СППР) надаватимуться альтернативні варіанти рішення щодо коригування відповідних планів для поліпшення показників, виходячи 3 ресурсних можливостей держави.

Таким чином, КPI щодо ефективності управління організаиійною структурою $\boldsymbol{O} \epsilon$ одним з тих, щчо характеризуе стан управління структурною одиницею (елементом) ЗС України в иілому. Сукупність КРІ за всіма структурами характеризує стан управління ЗС України в иілому.

Наведемо приклад впровадження ключового показника ефективності для окремої механізованої бригади [15]:

КРI $(\boldsymbol{D}$, завдання) - різниця у відсотках між набутими спроможностями щодо завдань, які бригада спроможна виконати, та вимогами до спроможностей щодо виконання завдання бригадою за певним сценарієм на конкретний час:

$$
D_{\text {омбр }}(i, j, t)=\frac{\left\lfloor D_{\text {вспр }}(i, j)-D_{\text {нспр }}(i, j, t)\right\rfloor}{D_{\text {вспр }}(i, j)},
$$

де $D_{\text {вспр }}(i, j)$ - вимоги до спроможностей $i-1$ бригади за $j$-им сценарієм;

$D_{\text {нспр }}(i, j, t)$ - набуті спроможності $i$-ї бригади за $j$-им сценарієм, на час $t$.

Для зручності сприйняття отриманих значень КРІ доцільно здійснити візуалізацію показників. На рис. 2 схематично відображено ступінь $D_{\text {омбр }}(i, j, t)$ у відсотках, де шкала показників розподіляється по трьох зонах: зелена, жовта та червона.

Зелена зона відображає набуті спроможності бригади щодо виконання завдання за певним сценарієм відносно до визначених вимог (у відсотках) - допустима зона $D_{\text {омбр }}(i, j, t) \geq D_{\text {нспр /в спр }}^{\text {ЗЕЛ }}$.

Жовта зона показує, що для виконання завдань бригаді потрібен певний час для набуття допустимих спроможностей, тобто $D_{\text {нспр / вспр }}^{3 Е Л} \geq D_{\text {омбр }}(i, j, t) \geq D_{\text {нспр/вспр }}^{\text {ЖОВ }}$.

Червона зона - означає неспроможність бригади виконувати поставлені завдання, $D_{\text {омбр }}(i, j, t) \leq D_{\text {нспр /вспр }}^{\text {ЖОВ }}$.

Аналогічним шляхом розробляються КРІ для решти критеріїв планування на основі спроможностей за принципами DOTMLPF.

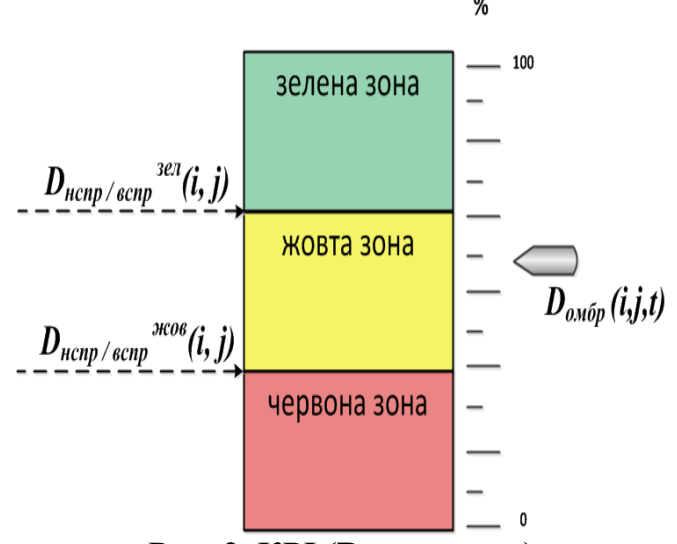

Рис. 2. КРІ (D, завдання)

Розглянемо особливості оцінювання ефективності управління організаційною структурою Збройних Сил України на основі використання КPI. Цей процес передбачає здійснення таких кроків:

аналіз бізнес-процесів організаційного менеджменту;

аналіз наявного стану елементів організаційної структури; 
формування завдань стосовно розвитку елементів організаційної структури (утримання, нарощування, формування, скасування);

формування ключових показників, які характеризують ефективність управління організаційною структурою " $\boldsymbol{K P I} \boldsymbol{O}^{\text {“; }}$

розрахунок "KPI O" на визначений (контрольний) момент часу;

коригування планів щодо приведення організаційної структури ЗС України в цілому відповідно до перспективної моделі 3С України.

Для адекватного реагування на кризові ситуації в органах організаційномобілізаційного планування ЗС України відповідно до Плану реформування ЗС України проводяться відповідні організаційно-штатні заходи. До того ж відповідальність за своєчасне i якісне проведення таких заходів згідно 3 повноваженнями розподіляється на різні ієрархічні рівні підпорядкування стратегічний, оперативний, тактичний (рис. 3).

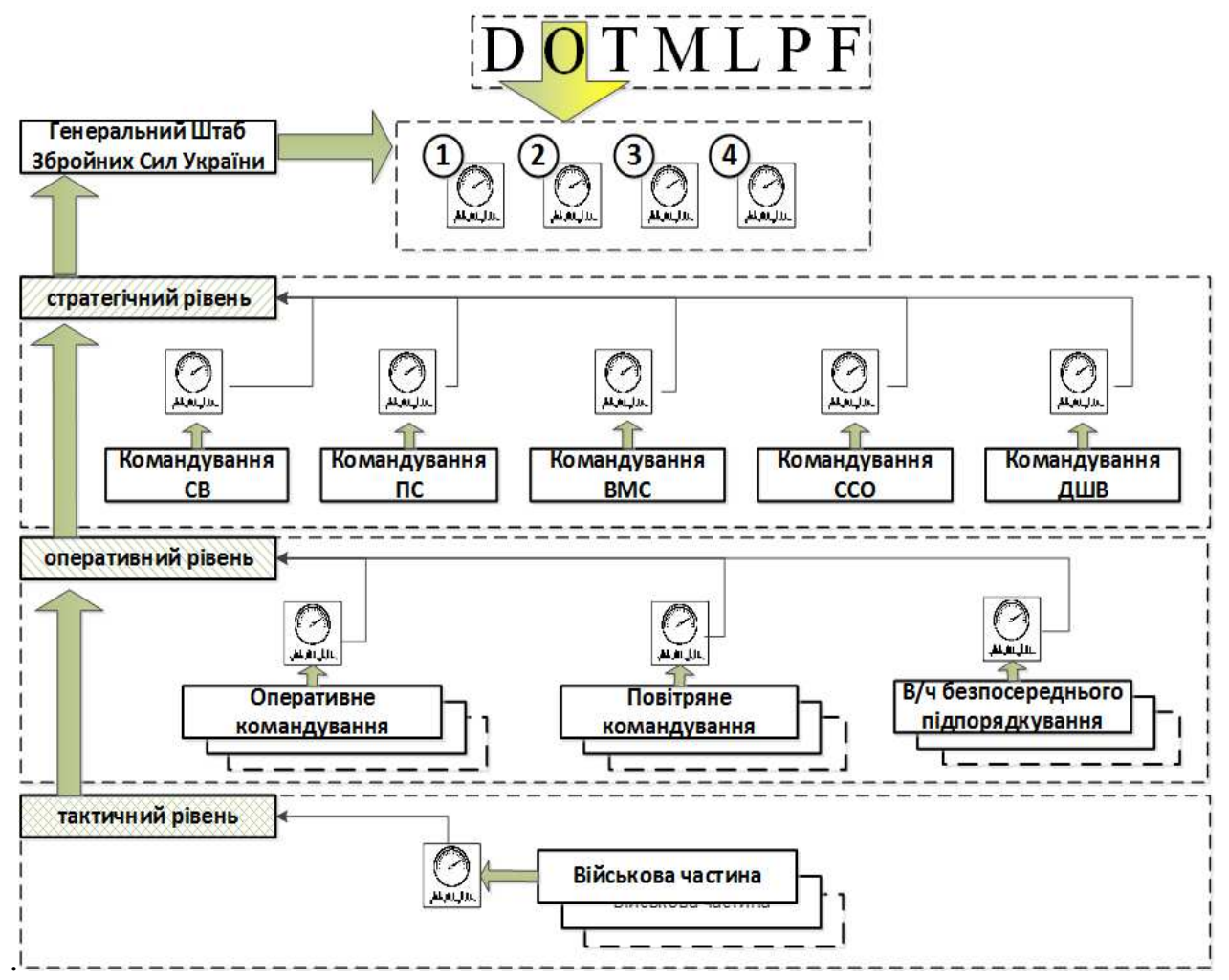

Рис. 3. Рівні управління Збройними Силами України

Планування організаційно-штатних структур видів збройних сил, оперативних командувань, військових частин і підрозділів полягає у проведенні організаційно-штатних заходів, тобто управлінні бізнес-процесами організаційного менеджменту, основні 3 яких наведено у табл. 2.
Кожний бізнес-процес розглядається на тому ієрархічному рівні управління, посадові особи якого відповідають за його проведення. Саме тому для здійснення моніторингу ступеня виконання організаційно-штатних заходів $\boldsymbol{K P I}$ впроваджуються на всіх рівнях управління (табл. 3).

Таблиця 2

\begin{tabular}{|c|l|}
\hline № & \multicolumn{1}{|c|}{ Назва організаційно-штатного заходу } \\
\hline 1 & Створення військової частини \\
\hline 2 & Розформування військової частини \\
\hline 3 & Перепідпорядкування військової частини \\
\hline 4 & Переформування військової частини \\
\hline 5 & Надання військовій частині нових дійсних та умовних найменувань \\
\hline 6 & Передислокація військової частини \\
\hline 7 & Створення підрозділу \\
\hline 8 & Розформування підрозділу \\
\hline 9 & Переформування підрозділу \\
\hline 10 & Створення штату (штатних посад) \\
\hline 11 & Внесення зміни до штату (штатних посад) \\
\hline 12 & Перехід на інший штат \\
\hline 13 & Скасування штату \\
\hline 14 & Ведення довідників опису посади (вимог до посади) \\
\hline
\end{tabular}




\begin{tabular}{|c|c|c|c|}
\hline $\begin{array}{l}\text { № } \\
\text { 3/II }\end{array}$ & Ключові показники ефективності & $\begin{array}{c}\text { Організація, в органі } \\
\text { управління якої } \\
\text { впроваджується КРІ }\end{array}$ & $\begin{array}{c}\text { Рівень } \\
\text { управління }\end{array}$ \\
\hline \multirow[t]{2}{*}{1} & \multirow{2}{*}{$\begin{array}{l}\text { Кількість (у \%, в од.) військових частин, які: } \\
\text { - створюються; } \\
\text { - розформовуються; } \\
\text { - перепідпорядковуються; } \\
\text { - переформовуються; } \\
\text { - передислокуються; } \\
\text { - переходять на інший штат }\end{array}$} & Види ЗС України & стратегічний \\
\hline & & $\begin{array}{c}\text { Оперативні командування } \\
\text { військ (сил) }\end{array}$ & оперативний \\
\hline \multirow[t]{2}{*}{2} & \multirow{2}{*}{$\begin{array}{l}\text { Кількість (у \%, в од.) підрозділів, які: } \\
\text { - створюються; } \\
\text { - розформовуються; } \\
\text { - перепідпорядковуються; } \\
\text { - переформовуються; } \\
\text { - передислокуються }\end{array}$} & $\begin{array}{c}\text { Оперативні командування } \\
\text { військ (сил) }\end{array}$ & оперативний \\
\hline & & Військові частини & тактичний \\
\hline \multirow[t]{3}{*}{3} & \multirow{3}{*}{$\begin{array}{l}\text { Кількість (у \%, в од.) штатів (штатних посад та } \\
\text { опис вимог до них) підрозділів, військових частин, } \\
\text { які: } \\
\text { - створюються; } \\
\text { - змінюються; } \\
\text { - скасовуються }\end{array}$} & Види ЗС України & стратегічний \\
\hline & & $\begin{array}{c}\text { Оперативні командування } \\
\text { військ (сил) } \\
\end{array}$ & оперативний \\
\hline & & Військові частини & тактичний \\
\hline \multirow[t]{3}{*}{4} & \multirow{3}{*}{$\begin{array}{l}\text { Кількість (у \%) категорій штатних посад (ШПК) у } \\
\text { відношенні до штатної чисельності: } \\
\text { - вищого офіцерського складу; } \\
\text { - старшого офіцерського складу; } \\
\text { - молодшого офіцерського складу; } \\
\text { - старшинського складу; } \\
\text { - сержантського складу; } \\
\text { - рядового складу }\end{array}$} & Види ЗС України & стратегічний \\
\hline & & $\begin{array}{c}\text { Оперативні командування } \\
\text { військ (сил) }\end{array}$ & оперативний \\
\hline & & Військові частини & тактичний \\
\hline
\end{tabular}

Ключові показники ефективності, запропоновані у табл. 3, згруповані у чотири групи за напрямами організаційно-штатних заходів. Взаємозалежність КРІ між рівнями управління (рис. 3) пропонується реалізувати в односторонньому напрямі так: показники реалізації організаційно-штатних заходів тактичного рівня (2-4 групи) будуть акумулюватись у показниках оперативного рівня, в свою чергу показники якої накопичуватимуться на рівні видів Збройних Сил України, тобто стратегічному рівні (14 групи). Узагальнення результатів досягнення ключових факторів успіху в цілому за Збройні Сили України, відповідно до вимог спроможностей реагування на сценарії кризових ситуацій за критерієм $\boldsymbol{O}$, доктрини DOTMLPF, здійснюватиметься в органах організаційно-мобілізаційного планування

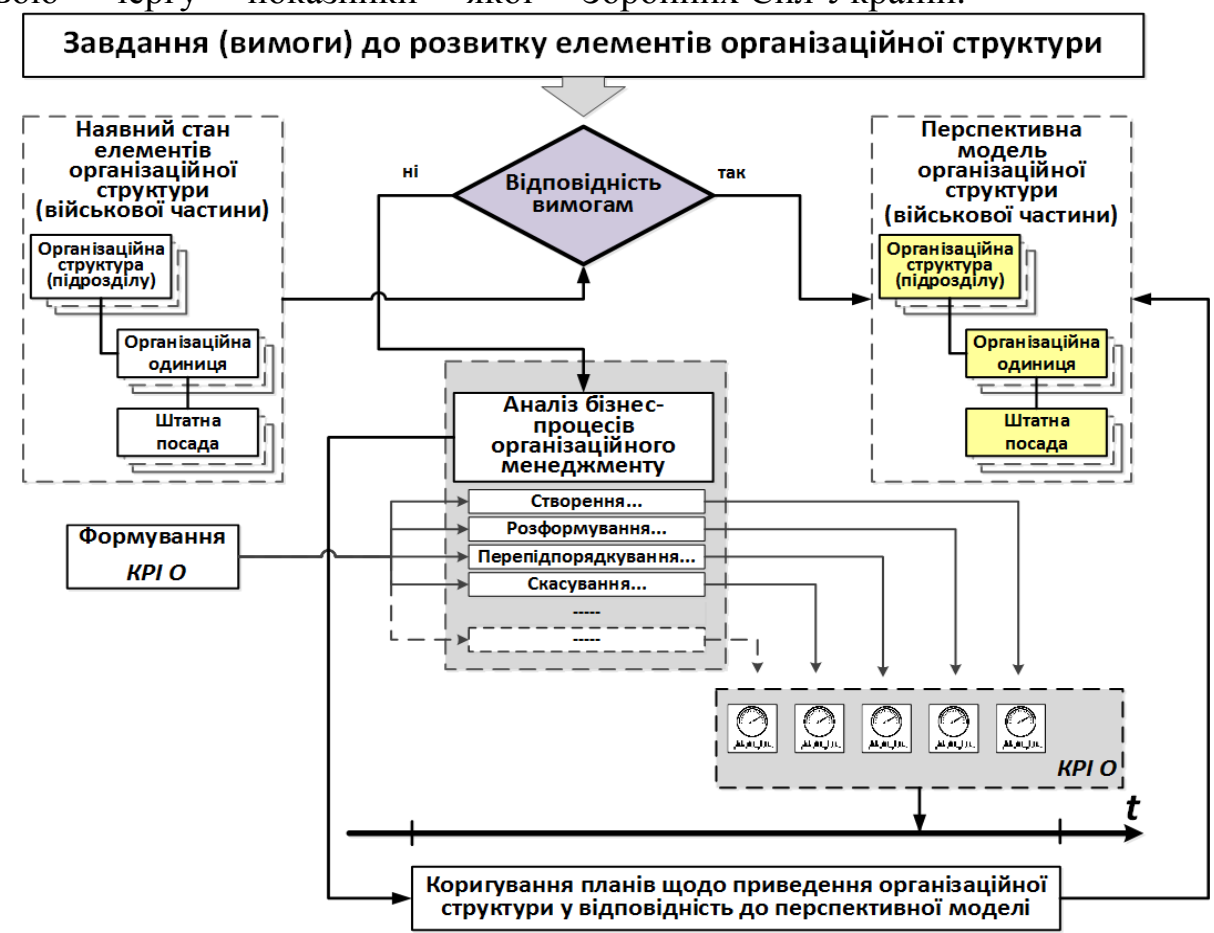

Рис. 4. Оцінювання ефективності організаційних заходів 
Приклад реалізації процесу оцінювання ефективності організаційного менеджменту щодо набутих спроможностей наведено на рис. 4.
Варіант візуалізації ключових показників ефективності на прикладі 1-ї групи стратегічного рівня управління (табл. 3 , п. 1), до якої входять шість КРІ, наведено на рис. 5.

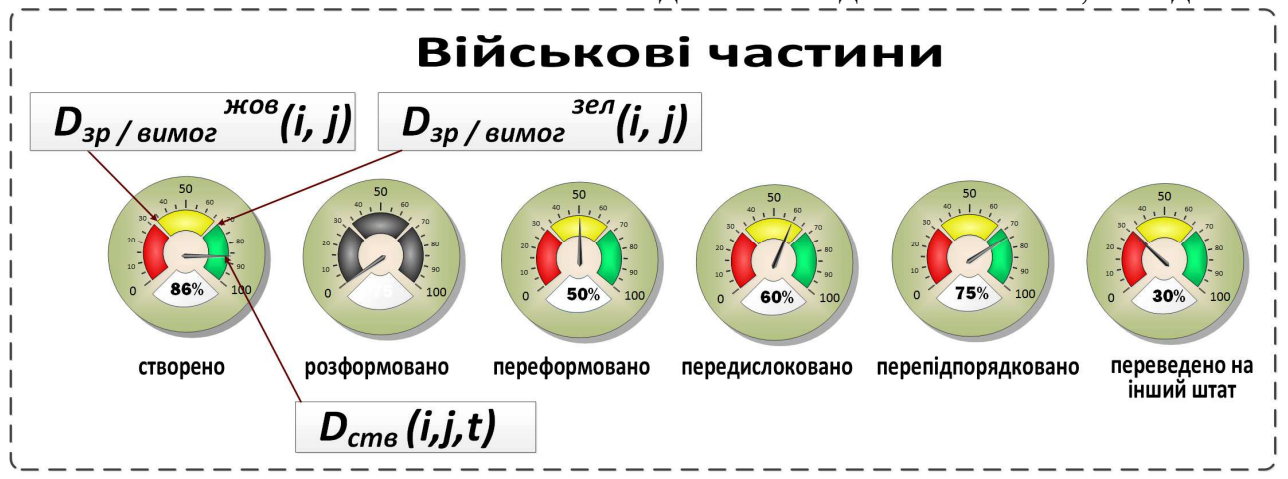

Рис. 5. Варіант візуалізації групи КРІ моніторингу виконання організаційно-штатних заходів у виді Збройних Сил України

Типовий $\boldsymbol{K P I}-D_{c n d}(i, j, t)$ (створено) різниця у відсотках між кількістю виконаних організаційно-штатних заходів зі створення військових частин, та вимогами спроможностей щодо організаційно-штатної структури для успішної реалізації визначеного сценарію на конкретний час:

$$
D_{\text {ств }}(\mathrm{i}, \mathrm{j}, \mathrm{t})=D_{3 p}(\mathrm{i}, \mathrm{j}, \mathrm{t}) / D_{\text {вспр }}(\mathrm{i}, \mathrm{j})
$$

де $D_{\text {вспр }}(\mathrm{i}, \mathrm{j})$ - вимоги до спроможностей $i$-го виду 3С України, $j$-го сценарію;

$D_{\text {зр }}(\mathrm{i}, \mathrm{j}, \mathrm{t})$ - створено військових частин $i$ го виду ЗС України, $j$-го сценарію, на час $t$.

Стрілка індикатора $D_{c m s}(i, j, t)$ показує значення виконання заходів у відсотках. Шкала показників індикатора розподіляється по трьох зонах: зелена, жовта та червона, як було розтлумачено на прикладі (рис. 3).

Висновки. Запропонована модель моніторингу організаційно-штатних заходів $\epsilon$ складною масштабованою за рівнями управління системою, де керівник органу управління на кожному ланцюгу, здатен оцінити ступінь виконання завдання на поточний час, скоригувати подальші дії в інтересах виконання завдання та приймати раціональні управлінські рішення.

Автоматизований аналіз даних на кожному рівні управління дасть змогу в органах управління Генерального Штабу та видів Збройних Сил України, оперативно формувати контингенти військ (сил), які на певний проміжок часу дислокуються у відповідних операційних зонах та у своїй сукупності відповідають набутим спроможностям для вирішення поставленого завдання.

\section{СПИСОК ВИКОРИСТАНОЇ ЛІТЕРАТУРИ}

1. Ключові показники ефективності. Матеріал з Вікіпедії. [електронний ресурс]. / режим доступу: https://uk.wikipedia.org/wiki/ Ключові_показники_ефективності

2. Указ Президента України від 22.03.2017 № 73/2017 "Про рішення Ради національної безпеки і оборони України від 29.12.2016 року "Про Державну програму розвитку Збройних Сил України на період до 2020 року”.

3. Указ Президента України від 20.05.2016 № 240/2016 “Про рішення Ради національної безпеки і оборони України від 20.05.2016 року "Про Стратегічний оборонний бюлетень України".

4. Указ Президента України від 26.05.2015 № 287/2015 “Про рішення Ради національної безпеки і оборони України від 06.05.2015 року "Про Стратегію національної безпеки України".

5. Закон України від 21.06.2018 № 2469-VIII "Про національну безпеку України".

6. Указ Президента України від 24.09.2015 № 555/2015 “Про рішення Ради національної безпеки і оборони України від 02.09.2015 року "Про нову редакцію Воєнної доктрини України".

7. Указ Президента України від 14.03.2016 № 92/2016 “Про рішення Ради національної безпеки і оборони України від 04.03.2016 року "Про Концепцію розвитку сектору безпеки i оборони України”.

8. Друкер, Питер Фердинанд. Матеріал з Вікіпеді i. [електронний ресурс]. / режим доступу: https://ru.wikipedia.org/wiki/Друкер,_Питер_Фер динанд\#Сочинения

9. David P. Norton. Матеріал з Вікіпедії. [електро нний ресурс]. / режим доступу: https://en.wikipedia.org/wiki/David_P._Norton 10. Приходченко Л. Л. Щодо складності застосування показників оцінювання ефективності державного управління: теорія і практика. // Державне будівництво. - 
№ 12009 р. - Режим доступу:

http://nbuv.gov.ua/UJRN/DeBu_2009_1_9

11. Кузьмук O.I. Еволюція структури Збройних Сил України. // Військово-науковий вісник. 2011. - Вип. 16. - С. 47-63. - Режим доступу: http://nbuv.gov.ua/UJRN/vnv_2011_16_7

12. DOTMLPF. Матеріал з Вікіпедії. [електронний pecypc]. / режим доступу: https://en.wikipedia.org/ wiki/DOTMLPF

13. Рекомендації 3 оборонного планування на основі спроможностей в Міністерстві оборони України та Збройних Силах України, затверджені Міністром оборони України від 12.06.2017 [електронний ресурс]. / режим доступу:http://www.mil.gov.ua/ content/other/Recommendationson_CBP_120617.pd f

14. Прокопенко О. С. Інформаційні панелі, як засіб підвищення ефективності управління оборонними ресурсами. / Турейчук А. М., Рибидайло А .А., Галаган В. І., Бондарчук С. В. - K., ISSN 2304-2699. Збірник наукових праць Центру воєнно-стратегічних досліджень Національного університету оборони України імені Івана Черняховського. - № 3(55), 2015 р.

15. Нетесін I. Є. Визначення ключових показників ефективності процесів матеріальнотехнічного забезпечення військового призначення. / Поліщук В. Б., Сапожнік А. І. К. - 2016. Збірник наукових праць та матеріалів науково-практичного семінару "Методологічні питання інформатизації логістики в управлінні оборонними ресурсами". 09.12.2016.

16. Defense and Security. [електронний pecypc]. / режим доступу: https://www.sap.com/ industries/defense-security.html

Стаття надійшла до редакції 06.08.2018

Прокопенко А. С.;

Рыбыдайло А. А., к.т.н., с.н.с.;

Турейчук А. Н., к.т.н.;

Руденская Г. В.

Центр военно-стратегических исследований Национального университета обороны Украины имени Ивана Черняховского, Киев

\section{Ключевые показатели эффективности управления организационной структурой вооруженных сил}

Резюме. Рассмотрены вопросы обоснования, разработки и внедрения ключевых показателей эффективности управления организационной структурой Вооруженных Сил Украины.

Ключевые слова: КРІ; ключевой показатель эффективности; организационная структура; планирование организационной структуры на основе возможностей; доктрина DOTMLPF; DRMIS.

\section{A. Prokopenko;}

A. Rybydajlo, Ph.D, senior researcher;

A. Tureychuk, Ph.D;

G. Rudenska

Center for Military and Strategic Studies of the National Defence University of Ukraine named after Ivan Cherniakhovskyi, Kyiv

Key indicators of the effectiveness of the management of the organizational structure of the armed forces

Resume. The issues of substantiation, development and implementation of key performance indicators for management of the organizational structure of the Armed Forces of Ukraine are considered.

Keywords: KRI; key performance indicator; organizational structure; capacity building planning; DOTMLPF doctrine; DRMIS. 